\title{
O INVESTIGADOR LIBERTINO E A INFÂNCIA COMO INDETERMINADO: A escrita científica enquanto ethos inventivo em duas propostas de autorreflexão e desterritorialização do sujeito escolar
}

\author{
Tomás Vallera \\ Universidade de Lisboa - ULisboa, Portugal \\ Tiago Almeida \\ Instituto Politécnico de Lisboa - IPLisboa, Portugal
}

\begin{abstract}
Resumo
Este artigo encena um diálogo metodológico entre dois projetos de investigação em curso: $O$ investigador libertino - A pesquisa como exercício de exteriorização do pensamento e de transformação da vida e Educação da infância como rito de iniciação - Essência, método e arquétipo. Com base no princípio de que a conversa sobre o conteúdo de uma pesquisa é inseparável da reflexão sobre a construção do seu objeto, e de que é no encontro com o outro que se descentraliza, amplifica e relança o pensamento para lugares antes impensáveis, propõe-se o cotejo de dois trajetos de investigação que, de modos distintos mas através de conceitos comuns (incapturável ou indeterminado; agenciamento e devir), defendem a uma só voz a escrita científica na área das Humanidades como possibilidade de aceder a um ethos inventivo, de exercer a autorreflexão e de deslocar o investigador em relação à sua condição de sujeito escolar. O libertino e a criança cumprem, aqui, a função de espelhar o lugar vulnerável e potente do investigador, figura que oscila entre um dispositivo que o captura e determina e um espaço indeterminado onde se experimenta a possibilidade de articular o que a escola historicamente separa: o estar-a-ser e o estara-fazer, a vida e o pensamento.
\end{abstract}

Palavras-chave: Investigação; Escrita Académica; Inventividade; Libertino; Infância.

\begin{abstract}
This article is a methodological dialogue between two on-going research projects: The libertine researcher - Inquiry as an exercise in the exteriorisation of thought processes and the transformation of life and The education of children as an initiation rite - Essence, method and archetype. Based on the notion that discussing the contents of a research project is inextricable from reflecting on the construction of the object of study itself; and on the idea that it is by encountering the other that one can decentralise, amplify and redirect one's thought processes towards the unforeseen, we propose an exchange between two research itineraries linked by a common conceptual framework (elusive or indeterminate; assemblage and becoming). Both inquiries promote the idea of scientific writing in the Humanities as a possibility to access an inventive ethos, to exercise self-reflection and dislodge the researcher from his condition as a school subject. The libertine and the child are used to display the fragile and potent condition of the researcher, a figure who oscillates between an apparatus that captures and defines him, and an undetermined space where he may experience the potentiality of uniting that which schooling has historically separated: being and invention, life and thinking.
\end{abstract}

Keywords: Research; Academic Writing, Inventiveness; Libertine; Childhood. 
Fazer sem totalmente saber o que se faz, é dar-se uma possibilidade de descobrir naquilo que se faz algo que se desconhecia. (Bourdieu, 2016, p. 19).

No fundo, não escrevo porque tenho alguma coisa na cabeça, não escrevo para demonstrar aquilo que já, no meu foro interior e para mim mesmo, demonstrei e analisei. A escrita consiste [...] em empreender uma tarefa graças à qual e ao final da qual poderei [...] encontrar alguma coisa que não tinha visto inicialmente. Quando começo a escrever [...] qualquer coisa, não sei realmente aonde [...] vai, nem em que vai dar, nem o que demonstrarei. Só descubro o que tenho para demonstrar no próprio movimento da escrita, como se escrever fosse precisamente diagnosticar aquilo que eu queria dizer no exacto momento em que comecei a escrever. (Foucault, 2016, p. 49)

\section{Introdução}

A reflexão que se segue constitui uma espécie de prestação de contas, diante de nós próprios como investigadores e perante o nosso coautor enquanto pensador-amigo, sobre duas pesquisas em andamento. Apresenta-se, acima de tudo, como um diálogo metodológico - conversa agradável, porém difícil e exigente, em que cada interlocutor consente usar apenas dos direitos conferidos pelo outro, deixando que as singularidades de cada pesquisa surjam dentro de um quadro conceptual comum e previamente acordado - que coloca em espelho o estar-a-ser da escrita académica e a natureza artesanal dos próprios objetos de estudo. $\mathrm{O}$ princípio fundamental subjacente a esta parceria é o de que a conversa sobre o tema ou o conteúdo de uma tese é inseparável da discussão sobre a construção do seu objeto. Como se não houvesse separação, pois, entre aquilo de que um texto fala e o modo como é concebido (Deleuze \& Guattari, 2007, p. 22).

Três condições preliminares, comuns a ambas as investigações, estiveram na génese deste diálogo. Em primeiro lugar, o facto de serem trabalhos em curso e, como tal, mobilizáveis sobretudo com o intuito de explicitar escolhas metodológicas ou problemas relativos ao ato de criação, mais do que com a pretensão de discorrer a partir de raciocínios conclusivos, enunciados fechados ou teses já terminadas e defendidas. Dois projetos que se expressam, portanto, a partir de um empirismo tacteante que não conhece de antemão o seu percurso ou destino. Recorrendo a interpretações muito particulares dos conceitos de libertino e de criança, este texto procura salientar uma convivência errante e lúdica do investigador com os seus objetos de estudo, esquivando-se quer da "arte da distância" e das dinâmicas da "compreensão" que definem a cognição escolar e a relação do aluno com os saberes ministrados pelo professor na sala de aula (Rancière, 2010, p. 12-13), quer do prosaico vínculo de gestão, propriedade e autoridade que o escritor-autor mantém com os livros que já escreveu e assinou (Barthes, 1975, p. 19). Segundo, existe nestes projetos uma afinidade de processo, na medida em que propõem, cada qual com os seus utensílios próprios, reconceptualizar e reatualizar tanto a libertinagem como a infância, partindo do princípio que toda a investigação é uma intempestiva regressão à origem, isto é, um exercício de permanente recuperação, absorção e relançamento da palavra escrita. Mas existe também um 
alinhamento estratégico no sentido em que, ao conceber-se o investigador libertino - a experiência intertextual enquanto modo de ser esquivo ou incapturável - e as delimitações históricas da infância como tentativas de determinar o indeterminado, se procura, nos dois casos, dirigir o olhar para o presente e refletir em conjunto sobre as relações entre docência, pesquisa e escrita inventiva. Por fim, acrescentaríamos que houve uma convergência temática, ainda que o referido tema não constitua o núcleo de qualquer uma das pesquisas tomadas individualmente. Com efeito, foi na troca de impressões proporcionada por esta iniciativa que a questão da escola como dispositivo que captura, determina e transforma o sujeito em criança e aluno[4], e cuja elaboração moderna teve uma etapa de extraordinário incremento no século das Luzes, saltou para o primeiro plano e permitiu abrir um espaço intertextual partilhado onde se cruzaram os tópicos do aluno libertino e da infância escolarizada.

Além dos temas do incapturável e do indeterminado, convocámos para a construção deste texto dois conceitos operativos: agenciamento e devir. Nas palavras de Deleuze e Guattari (2007), o agenciamento é um arranjo ou combinação de elementos heterogéneos, díspares, com a potencialidade de fazer surgir algo de novo, e que não se resume a nenhum dos elementos que o compõem. Encarna uma potência dupla: de contra-diferenciação, por um lado, mas também de contra-estabilização, contra-estratificação ou contra-solidificação, por outro. Nesse sentido, tanto pode abrir novas possibilidades como, pelo contrário, prender, capturar, cristalizar ou determinar. Os agenciamentos constituem-se estabelecendo relações entre diferentes elementos, afetos e variações, e podem fazer emergir, simultaneamente, forças delimitadoras de modos de ser, mas também forças de devir ou de criação contínua (Deleuze, 1962 [2018], p. 37).

No primeiro exemplo, os conceitos de devir e agenciamento foram utilizados como ferramentas para pensar i) a relação polícia-escola no contexto do Estado de polícia do século XVIII e ii) a possibilidade de conceptualizar o investigador como um modo de ser libertino no presente. Por um lado, define-se um agenciamento dito histórico, que ainda ressoa na atualidade (o investigador é um sujeito escolarizado), e, por outro, um agenciamento artesanal, decorrente de uma pesquisa singular, local e contingente em torno da relação entre pesquisa e formas de vida libertinas. No segundo, os mesmos conceitos foram mobilizados para i) problematizar o par criança-futuro no contexto da educação da infância a partir do século XVIII e ii) pensar a infância como um modo de existência indeterminado na contemporaneidade. Neste caso, o agenciamento histórico corresponde às forças que circunscrevem e determinam quem é e como se é criança, enquanto o agenciamento contemporâneo, no confronto com o anterior, descreve uma possibilidade de modos de existência indeterminados. 


\section{2. $O$ investigador libertino}

\subsection{Argumento e metodologia}

Neste segmento, trata-se de fazer uma aproximação, ainda preambular e longe de qualquer proposta definitiva ou conclusiva, aos temas da investigação, do lugar e função do investigador académico, a partir de uma problematização histórica em torno do conceito de libertino. O que sucederia aos conceitos de investigador e libertino, e que ilações poderíamos retirar para um pensamento sobre a investigação científica, se, por hipótese, considerássemos o investigador, no estar-a-escrever do seu texto, um modo de ser libertino? Assim, e no encalço desse "como se" que Derrida associa à natureza do questionamento académico no âmbito das Humanidades (2003, p. 23-33), sugere-se aqui a eventualidade de fazer como se o trabalho da escrita, o Handwerk do pensamento (1987, p. 171), consubstanciasse um tipo de libertinagem. Consequência dupla: i) o surgimento de uma reatualizada concepção de libertino, vinculada por diferentes vias às múltiplas formas que essa figura assumiu no passado, mas distinta de qualquer uma delas; ii) um deslocamento de perspectiva sobre o que significa investigar, abrindo-se, desse modo, a possibilidade de estimular outras conversas sobre o trabalho científico no presente.

Na prática, esta pesquisa constitui-se com base num procedimento tópico, isto é, fazendo com que a noção de investigador - aquele que "segue as pegadas" que "procura com cuidado" ou busca "verdades ocultas" (Machado, 1977, p. 319; Bluteau, 1713, p. 185) - atravesse uma grelha de leituras que procura identificar e mapear variadas ocorrências da figura do libertino. Em suma, trata-se de fazer com que a busca da verdade passe pelo crivo de uma etologia (Deleuze, 2002, p. 25, 130-131) da libertinagem; de fazer deambular o tema da escrita científica como desejo e fantasma pelo multiforme arquivo das vidas libertinas.

Os libertinos aparentam, porém, ser tantos quanto os grémios ou indivíduos que assim foram sendo qualificados. Entre os chamados "barrocos", houve-os ora fideístas, ora panteístas, eruditos ou sensualistas, discretos ou extravagantes, eclesiásticos ou leigos (Onfray, 2008). A cronologia devolve-nos os "espirituais" do século XVI, os homens de ciência e "espíritos fortes" seiscentistas e, por fim, os aventureiros e burlões, os grandes sedutores e os devassos do século das Luzes, que ainda hoje predominam no imaginário coletivo. Uma visão mais geral deste fenómeno revela que podem ser reais ou ficcionais, indivíduos ou coletivos, que protagonizam a sua emancipação ou são alforriados por terceiros (o libertinus ou escravo liberto, em Roma), que ora podem ser definidos pelo discurso que os condena e avilta, ora assumir eles próprios essa derivação, esse movimento de saída em relação a um estado anterior (ou existente) e prevalente. Em todo o caso, e apesar de todas estas variações, o libertino parece abranger as questões do deslocamento, da saída, da evasão ou da digressão vinculadas a tempos e contextos específicos. Nesta óptica, o investigador libertino não corresponderia a um estatuto, posição ou profissão - sábio ou aprendiz (Vallera \& Paz, 2014), professor ou aluno, licenciado ou pós-graduado, bolseiro ou contratado -, mas antes a uma condição ou modo de ser. Tal conceito poderia ser designado por inatual ou intempestivo, na medida em que diverge, em simultâneo, do que seria a sua interpretação 
corrente - a espirituosa imagem de um académico libidinoso - e das representações que os homens dos séculos XVII e XVIII nos devolveriam do termo - um "inquisidor" ateu, por hipótese, ou um "escrutador" que seria ao mesmo tempo sedutor compulsivo ou inveterado racionalista.

Idear esta personagem não consiste, portanto, em descrever o que o investigador ou o libertino já foram in illo tempore, nem definir aquilo que essa figura seria no presente, com o sentido que atualmente atribuímos a essas palavras. Não se trata, muito menos, de delinear um libertino ou um investigador (ou uma conexão entre ambos) que seriam válidos e fixos para todos os tempos e contextos. Para nos constituirmos herdeiros destes legados históricos que nunca cessaram de reatualizar duas questões essenciais (a da investigação, agregada à busca zelosa da verdade; a do libertino, associada à emancipação da vida ou do pensamento), produzindo a diferença em cada reiteração, cumpre fazer com que essa noção de investigador libertino responda a problemas formulados hoje, nas circunstâncias em que vivemos, e no interior dos ofícios ou ocupações que são os nossos. O estudo da natureza libertina do investigador corresponderia, assim, a uma prática autorreflexiva.

\subsection{O agenciamento polícia-educação na genealogia do sujeito escolar}

Além desse efeito de retorno sobre o próprio trabalho, em que a constelação dos modos de ser libertino foi mobilizada como alavanca para (re)pensar o ofício do pesquisador, este projeto em curso centra-se também no movimento de exteriorização. Crítica reflexiva e autoconsciência dos processos de construção da pesquisa, portanto, mas com base nesse vínculo entre desterritorialização pelo conhecimento e transformação da vida. Que tipo de deslocamento e que possibilidade de transfiguração encarna, afinal, essa personagem? A ideia-chave que orienta esta pesquisa é a de que o investigador libertino expressa a peculiar circunstância do sujeito escolarizado a partir do momento em que se deixa guiar pelo desejo de escrever ou investigar. É no movimento de saída do espaço cognitivo da escola procurando emancipar-se, antes de mais, de si mesmo - que reside a singularidade da sua libertinagem. Mais do que uma saída da escola no sentido de uma transição (aquela que ocorre, por exemplo, na passagem da educação secundária para o ensino superior) ou de uma evasão ou desobediência às normas da instituição escolar (conduta esquiva, relapsa ou refratária do aluno libertino), esta variante da exteriorização refere-se à relação do sujeito da escrita com uma herança que o constitui integralmente e que, desde a infância, vem restringindo e consolidando o seu encontro com os saberes no princípio do reconhecimento (Ó, 2019, p. 276-277, 352).

Numa pesquisa anterior, abordou-se a constituição desse dispositivo escolar moderno a partir de um dos seus mais decisivos pontos de proveniência: a confluência, durante o século XVIII, do discurso educativo de vanguarda com as práticas e os saberes de polícia, cujos exemplos maiores em Portugal foram as "casas de educação" da Casa Pia de Lisboa e o Colégio dos Nobres, autênticos "laboratórios da modernidade pedagógica". Esse estudo permitiu compreender como, várias décadas antes do advento do modelo liceal, a personagem 
do aluno aprendente e escrevente - aquele que lê e escreve para sintetizar, comentar ou reconhecer a verdade definitivamente expressa no manual escolar - já havia sido intensamente pensada, discutida e experimentada (sob os preceitos da ciência da polícia, por intermédio da qual se procurava engendrar a conformidade entre a população e os superiores interesses do soberano) no contexto de uma política de "governo geral do Estado" (Vallera, 2019).

No século XVIII ocorre, efetivamente, uma muito declarada confluência processual entre a polícia geral do Estado como panaceia governamental e as mais progressistas ideias no campo da pedagogia: governa-se com mais eficácia, maior profundidade e economia de meios, quando a obediência é engendrada a partir da interioridade (Innerlichkeit) dos sujeitos e decorrente de um trabalho de condução da sua vontade. O tema da obediência como convicção íntima - um coração, um cérebro ou uma alma cujos afetos ou raciocínios podem ser conduzidos de tal modo que o cumprimento das obrigações seja vivido como uma série de atos livres ou voluntários - permeia de forma explícita as reflexões sobre a arte de governar enunciadas por um grande número de pensadores, legisladores e governantes europeus, mas também o discurso da expertise pedagógica coetânea (Vallera, 2019). Como adiante se demonstrará, igualmente, com a sequência Rousseau-Pestalozzi-Froebel, um mesmo preceito governamental norteia i) a produção de "súbditos iluminados" como estratégia de consolidação e de fortalecimento do Estado moderno nos tratados de polícia e ii) a condução do espírito da criança numa tratadística educacional cada vez mais partidária do modelo colegial, essa heterotopia que afiançava a produção de súbditos polidos ou policiados nos quais se intersectam os princípios da autonomia, da emulação, da submissão e da utilidade.

Assim, e mobilizando através de Deleuze um dos conceitos operativos desta parceria, poder-se-ia asseverar que o dispositivo escolar - designadamente aquele que se identificou através da correlação polícia-educação - constitui um agenciamento histórico cujos componentes (técnicas, mecanismos, instrumentos e saberes especializados) foram coalescendo e orbitando, acima de tudo, em torno das questões de conduzir a vontade dos alunos e de evidenciar a criança na sua mais completa legibilidade (Vallera, 2019, p. 622).

Teríamos, assim, uma multiplicidade sedimentada na longa duração, com diversas procedências nos séculos XVI-XVII e um período de pronunciada cristalização no Estado de polícia da segunda metade do século XVIII. A essa extensa genealogia do sujeito escolar moderno, que descobre as suas principais proveniências na devotio moderna, nos colégios da Universidade de Paris e na pedagogia jesuítica (Ó, 2019, p. 308-359), a polícia acrescentou um conjunto de imperativos: i) estatização do ensino; ii) afirmação do Estado educador como entidade totalizante que se apoia num modo de veridicção científica; iii) formação de "súbditos iluminados" - populações recrutadas no cume e no sopé da escala social e albergadas em sistema de internato - cuja "felicidade" devia ser indestrinçável da sua utilidade para o "bem geral"; iv) gestação de uma "nobreza natural", ou o polimento pela educação como carreira moral e narrativa de salvação; v) adaptação do "agostianismo político" ou "cristianismo patriótico", "interessado na criação do modelo de cidadão a partir do exemplo sacrificial da religião, do espírito e da introspecção", a uma polícia cristã 
orientada para um projeto de conformidade social; vi) articulação, no mais íntimo do sujeito de conhecimento, entre vontade e dever, autonomia e obediência (Vallera, 2019, p. 541-542, 611); e, por último, vii) transformação alquímica (Popkewitz, 2002, p. 262) dos saberes literários e científicos em disciplinas de um conhecimento útil e policiado, não se procurando neste "verdadeiro caminho" senão incorporar e reconhecer "o bom, o útil e o sólido" (Junta de Providência Literária, 1771, p. 312-313).

A figura do escolar como sujeito de polícia assenta, portanto, no princípio de que a relação do aluno-ouvinte com a escrita, o seu confronto intensamente limitado, mediado e controlado com o infinito da linguagem, tem por desígnio fundamental produzir a conformidade. Significa isto que, havendo uma prática autorreflexiva na escola, esta não serve para conhecer ou tomar posse do que nos desalenta ou incapacita, daquilo que engendra a impotência, a auto-depreciação e a rarefação do arroubo inventivo, nem mesmo para ganhar consciência, em profundidade, dos métodos e processos de construção do pensamento. Se há nesse dispositivo uma invocação ao diálogo interior, se na implantação histórica da maquinaria escolar (Álvarez-Uría \& Varela, 1991) há uma constante intimação à relação de si para si, à objetivação de si mesmo, ela destina-se a produzir a ordem e a exercer o governo (Foucault, 2008, p. 164), a reconduzir o sujeito a uma ortopedia identitária mais do que aos mecanismos da invenção, a induzir uma percepção do saber que tende a apresentá-lo como produto acabado, total, esmagador e inacessível, mais do que como lugar de artesanato, experimentação e relançamento contínuo do discurso. No fundo, a autorreflexão corresponde aí, sobretudo, às exigências de, no âmbito didático, confirmar, repetir ou responder corretamente e de, no domínio da conduta, emular, conduzir e normalizar.

O mesmo poderia dizer-se sobre a temática da exteriorização. Quando assomam na escola - mais do que uma instituição, um regime cognitivo que se universalizou e nos acompanha durante toda a vida -, o movimento de saída, a exterioridade e a itinerância não equivalem a processos de diferenciação ou de singularização pela escrita, não se referem ao deslocamento contínuo que é inerente ao ato de pesquisar, nem tão pouco à ideia de uma viagem pelo desconhecido, na qual a "verdade" não seria um fim em si, mas uma espécie de horizonte intangível que extravia o sujeito-investigador do seu senso comum, das suas próprias convicções ou impensados. De facto, na gramática escolar (Tyack \& Tobin, 1994) que habita e engendra tanto o aluno como o investigador, as categorias do egresso remetem, em geral, para duas dinâmicas disciplinares interligadas: a progressão ou regressão no regime de classes e a conformidade ou desconformidade em relação à norma universal dos conteúdos pré-finalizados e dos sentidos canonicamente prescritos.

Sair de um estatuto para ingressar noutro significa ser promovido ou despromovido, graduado ou desgraduado, no interior de um sistema onde o sujeito é compelido a relacionarse consigo próprio, com os colegas e professores e com os saberes a assimilar, em função de uma norma que quantifica desempenhos, reduz desvios, determina lugares, distribui prémios e sanções (compensa-se elevando, castiga-se suspendendo ou desclassificando). Sair, na lógica da polícia escolar, nunca é uma evasão, mas um padecimento: o trabalho do aluno e a sua carreira moral na instituição estão sempre sujeitos a uma dialética normativa que ora outorga ou retira, agracia ou castiga, faz avançar ou recuar (Vallera, 2019, p. 638). 
Porém, sair ou exteriorizar-se no contexto escolar denota também a falha, o erro, a confusão, o descaminho ou o desgoverno. Deste ponto de vista, sair é cometer uma falta, desorganizar-se ou amotinar-se e, assim, colocar-se do "lado de fora". O aluno libertino insere-se por inteiro nessa extensa tradição de discursos e práticas de poder - com destaque para a polícia - que definem a libertinagem como seu limite e contrário, ou seja, enquanto espectro ou gradação de vícios e desvios da alma que medram no limiar de um espaço vigiado, esquadrinhado ou disciplinado que carece de ser ampliado. Na escola, o libertino é o potencial de erro, de falha ou desacerto (tendência para a irracionalidade), contumácia (pendor para a delinquência), indolência (inclinação para a ociosidade) e indecência (augurando a depravação) que existe em todos e cada um, e que o cotejamento com a norma faz aparecer a todo o instante na relação que o sujeito estabelece entre si e os outros, entre o que fez hoje e o que alcançou ontem, entre a facilidade que tem em acompanhar uma disciplina e os apuros que revela noutra, numa constante interlocução de si para consigo (Vallera, 2019, p. 634). Organizando a leitura e policiando o confronto com a escrita - e submetendo, nessa operação, a segunda à primeira -, foi por método, pois, que a modernidade educativa passou a designar a "perseguição de regras e etapas para as quais se tem de antemão uma resposta determinada", ou melhor, a "economia de meios e de investimento" que deve poupar o aluno "a esforços inúteis, tergiversações, jogos de acaso [...] ou indeterminações excêntricas; [preservá-lo] do passo em falso, do aleatório e dos caminhos ignotos, [fazendoo] andar sempre de forma gradual do mais simples para o mais complexo" com o propósito de alcançar "sem qualquer rotura ou descontinuidade" uma finalidade específica (Ó, 2019, p. 298). Nestes casos, a libertinagem - a saída enquanto fuga, ruptura, desvio, ziguezague, hibridez, dúvida, errância ou experimentação - nunca é mais do que um lapso, um desnorteio ou uma reacção encerrada e inteiramente capturada pelo discurso que a demarca e diagnostica. Dir-se-ia, no limite, que o aluno enquanto tal exerce sempre uma libertinagem conforme.

\subsection{O investigador libertino como movimento de exteriorização do sujeito escolar em relação a si próprio e em direção ao desconhecido}

Na figura do libertino condensa-se, pois, um deslocamento temático face a esse trabalho anterior em que a escola aparecia na confluência de vários mecanismos policiais, mas também um movimento de saída por meio do qual o investigador, em diálogo com um arquivo por ele fabricado, procura dar conta desse singular modo de ser que é a experiência intimidante e contraintuitiva para nós, sujeitos sobremodo alfabetizados - de pesquisar sem mediação e em função de um desejo de escrever, ou seja, de produzir um itinerário único e irrepetível no infinito da linguagem.

Poder-se-ia então sustentar, novamente a partir de Deleuze, que o sujeito escolar configura a nossa "história" (o desenho "do que somos" e estamos em vias de deixar de ser) e que a condição de investigador, por sua vez, encarna o "devir": o "atual", o acontecimento, ou o "esboço daquilo que nos vamos tornando" (2005, p. 93). No entanto, e tal como se 
verificou, o investigador enquanto libertino não aparece já dado, é necessário conceptualizálo. Longe de um dispositivo histórico elaborado na longa duração para responder a problemas de governo e administração populacional, ele constitui antes um agenciamento local, artesanal e contingente, criado de raiz com o objetivo de, por um lado, tentar evidenciar, obstruir e curto-circuitar o regime e a cognição policial-escolar que ainda hoje permeiam a vida e o trabalho universitário, e de, por outro, procurar aceder às categorias da exteriorização, isto é, aos diversos instrumentos de criação e de navegação no de fora do que sabemos ou do pensamento que já transportamos.

Um projeto desta natureza coloca em jogo uma tripla dinâmica que correlaciona êxodo, crítica reflexiva e transformação da percepção - e, por isso, do próprio ser - do sujeito da escrita no campo das ciências humanas. Primeiro, trata-se de sair em busca de um objeto já ideado mas ainda por construir, que se pretende circunscrever mas que é ele próprio indeterminado; de esquiçar um itinerário com múltiplas variações e ramificações a partir de um "centro" que é ao mesmo tempo fixo e móvel e que, pela sua índole experimental, compulsa a narrativa a devanear para logo se recentrar, "[deslocando-se] sem deixar de ser o mesmo e tornando-se sempre mais central, mais esquivo, mais incerto e mais imperioso" (Blanchot, 1987, p. 7).

Segundo, esta seria uma pesquisa que - nesse percurso em que nenhum rumo ou solução aparecem dados à partida e onde a questão fulcral não cessa de se revisitar e de se pensar a si mesma - habitaria plenamente a zona da dúvida, do vaivém, do estar-entre, dessa pura mecânica textual na qual se exerce a difícil e alegre arte de promover bons encontros, de incrementar a potência de agir (por contraste com a tristeza do padecimento), fazendo escolhas, sopesando e diagnosticando, discriminando o que é importante do que é supérfluo, o que faz crescer o texto e o que não lhe convém, numa constante submissão da leitura à escrita. Encenar-se-ia, assim, através dessa saída desfamiliarizante, uma relação especular com o próprio objeto da pesquisa: é justamente essa a superfície onde aflora o investigador libertino; o espaço no qual o risco do descaminho concorre com a eventualidade de aceder ao "multiforme da existência" e conceber "formas de pensamento-outro" (Ó, 2019, p. 82, 39).

Terceiro, esta condição in medias res, na qual a escrita não é senão uma contínua prática de reescrita, em que o fundamental reside na solidez das articulações mais do que no produto final, no processo de construção da narrativa e não tanto no valor intrínseco dos resultados alcançados, é também o lugar onde se desenvolve uma determinada ética do trabalho científico. Sair ou evadir-se, ainda que fugazmente, da escrevência (Barthes, 1975, p. 30-31) - ou da polícia da escrita - para o que seria uma fruição do texto, significa esquivar-se do princípio moral que governa a escola (que recorre a critérios abstratos, como a norma e o ideal, para assim exercer o julgamento), com a sua ordem explicadora (Rancière, 2010, $\mathrm{p}$. 12-13) e o seu propósito de assegurar um intransigente por vir adulto, envolvendo cada discente em jogos que determinam a identidade por conformidade-desvio com a lei e com enunciados universais.

A voz do investigador no momento em que está investido no processo de escrita - talvez aquela que é menos escutada nas nossas instituições de ensino -, apesar de poder coincidir 
com estes estatutos, não se pronuncia a partir do mesmo lugar que ocupam o professor e o aluno; o autor aclamado e o académico desanimado ou assustado (Nietzsche, 2003 [1872], p. 128-131, 151); o intérprete privilegiado que toma a palavra para restabelecer a unidade interna e a coerência essencial de um texto e o pesquisador neófito que responde ao sentimento de impotência concedendo a figuras autorizadas o poder de decretar a verdade, a solução ou a palavra final sobre a validade e o rumo da sua investigação. Exprime-se, em vez disso, no intertexto, ali onde os problemas do aprendiz são igualmente, e na devida proporção, os do pensador consagrado. $O$ investigador libertino não seria, pois, aquele que ocupa o estágio entre o estudo e o domínio de um saber, ou a etapa que separa o tirocínio da sagração. Ele seria antes um modo de persistir sempre no intervalo, atento ao detalhe e absorto nas questões técnicas da articulação entre fragmentos que só uma leitura fomentada e instrumentalizada pelo desejo de escrever pode fazer aparecer. A condição de investigador, portanto, não como uma época da vida (que começaria no início de uma pesquisa para se suspender no seu desfecho), mas como autêntica forma de vida (que perpassa os graus académicos e opera no nível elementar da transição entre frases, parágrafos, capítulos e textos). No estar-a-ser da escrita encena-se o ciclo ininterrupto de uma evasão que procura transcender a "moral dos deveres" para ingressar numa "ética da potência" (Deleuze, 2002, p. 110).

Adivinha-se, à partida, um conjunto de dificuldades nessa interação do tópico da investigação científica com o acervo dos modos de ser libertino. Como deverá ser construído esse repositório? Que critérios poderão determinar aquilo que será incluído ou excluído, as personagens ou coletivos que merecem maior destaque ou análise detalhada e as que servirão apenas de referência ou exemplo pontual? Ainda que seja ponto assente que os temas da saída e do deslocamento constituem o menor denominador comum, subsistem, contudo, alguns problemas fundamentais, entre os quais o facto de i) nem todos os libertinos desenvolverem práticas de escrita ou investigação; ii) uma grande parte dos assim denominados, como já se observou, não serem libertinos por afirmação própria, mas definidos enquanto tal por quem os censura; iii) existir uma série de pensadores mais recentes - Nietzsche, Blanchot, Bataille, Barthes, Foucault, Deleuze e Guattari, Agamben, mas também escritores como SacherMasoch, Lautréamont, Mallarmé, Kafka, Borges ou Beckett - que, não integrando necessariamente a categoria dos libertinos, criaram, no entanto, formas de trabalho experimentais que exploram os limiares do discurso e do pensamento recebido (com a respectiva retroação nos seus modos de existir), sendo elas próprias experiências-limite da escrita e da investigação. Abrir-se-ia, por este caminho, a possibilidade de ampliar o conceito (colhendo atributos presentes em personagens que não foram designadas por esse termo; excluindo porventura outros que habitualmente caracterizam a vida libertina, como o hedonismo e a imoderação sexual), uma vez que o investigador não é libertino do mesmo modo que, por exemplo, Gassendi ou Sade puderam sê-lo, nos seus peculiares modos de existência.

Estando a pesquisa no seu começo, e o arquivo ainda por delimitar, não fará aqui sentido expor senão algumas intuições fantasmáticas - forçosamente sumárias - sobre as variações em torno do tema da saída que poderão surgir neste catálogo. Na génese etimológica da 
palavra, o libertinus romano, descobre-se, por exemplo, o tópico - mais pertinente, neste caso, do que o problema da servidão - do indivíduo a quem é outorgada a liberdade, mas que nessa nova condição se vê ainda determinado, até ao fim dos seus dias, pelo estatuto que lhe foi imposto à nascença (Mouritsen, 2011, p. 36, 265). Na origem (Ursprung, no sentido nietzschiano) deste termo, descobre-se a ideia de uma emancipação que não liberta plenamente; de uma existência híbrida e ambivalente.

Também relevante para o tema da exteriorização do sujeito escolar através da pesquisa, seria a tradição comunitária de algumas vidas libertinas. Em coletivos como a bíblica sinagoga dos libertinos, os "espirituais" ou "espíritos fortes" dos séculos XVI e XVII, os enciclopedistas das Luzes e até os grémios maçónicos e os grupos revolucionários, poder-seia destacar não tanto o fervor religioso de uns ou o anticlericalismo de outros, mas, acima de tudo, a consciência de que é em comunidade que melhor se protegem interesses comuns e se podem enraizar formas de resistência a poderes de apropriação dogmáticos ou injustos. Assim é com o investigador, que no seu êxodo da escola parte em busca de uma comunidade de iguais ainda por convocar, um estar-a-ser-junto "na base um-com-o-outro" (Heidegger, 2008, p. 114, 155, 157) em que todos se encontrariam em estado de escrita e, como tal, capazes de compartilhar as dinâmicas, as flutuações e os aspectos práticos que definem esse exercício tão difícil quanto empolgante, tão desejado como obstruído dentro das nossas instituições científicas e educativas. Neste ponto, o pesquisador distancia-se do individualismo radical de libertinos como Sade e Don Juan. Mas procurar uma comunidade significa, também, ir constituindo a sua tribo intelectual, ir arrolando, entre vivos e mortos, as autoridades que aumentam a polifonia dos seus textos, que adensam e ampliam essa máquina de escrita para a qual vão sendo mobilizadas.

Ao concentrar-se nos aspectos propriamente artesanais da escrita - citar, canibalizar, articular, reescrever, enfim, deixar-se afetar pelo jogo da permuta textual -, o investigador aproxima-se, por um lado, da utensilagem metodológica e do princípio de uma arte da existência observáveis em autores como Benjamin, Kafka, Blanchot ou Foucault e, por outro, dos pensadores livres do século XVII e dos philosophes das Luzes, cujo ceticismo, racionalismo e materialismo aguerrido se insurge contra axiomas ou argumentos alicerçados na fé, na autoridade ou na transcendência. Essa vivência do intervalo, do estar-a-caminho, de uma errância cuidada e exigente e do cruzamento perpétuo de fragmentos, que é ao mesmo tempo uma experiência de dessubjetivação e dessacralização do livro e do autor, faz do investigador, na verdade, um cultor da escrita como exercício de pura imanência.

Em Espinosa, decerto uma das figuras de proa neste arquivo, descobre-se uma filosofia que é ontologia, ética e também estética da existência. Fugaz, incapturável, "imperceptível”, o autor da Ética está “sempre no meio, sempre em fuga apesar de não se agitar muito". Ele é o libertino racionalista, desterrado da comunidade judaica, que se evade dos poderes, que se esquiva "aos doentes e aos intriguistas" para lavrar na penumbra os seus cristais (Deleuze \& Parnet, 2004, p. 80-81). Nele correlacionam-se escrita e vida, pesquisa e autorreflexão. Longe de ser penitente, Espinosa apropriou-se das virtudes ascéticas - humildade, pobreza e castidade - para criar um pensamento radicalmente singular, fazendo deste, por sua vez, um verdadeiro modo de viver que, mais do que convencer, conduzir ou apontar um caminho 
único, procurava "somente inspirar, despertar" para uma existência "rica e superabundante" de "produção", "produtividade" e "potência" (Deleuze, 2002, p. 9).

Igualmente sui generis é a questão da autonomia em Kafka, cujo pai - descrito por Bataille como representante da ação eficaz do mundo dos adultos - entendia a emancipação no sentido prático, funcional e determinista: sair de casa dos pais significa casar-se, seguir uma carreira e fundar uma outra família. Paradoxalmente, isto era para Kafka o inverso de uma libertação, o caminho que o levaria a abjurar os prazeres lúdicos da escrita e a replicar a vida do pai, a figura que ele mais temia e de quem mais desejava desprender-se. Perseverar na escrita para, através dela, se evadir, foi, para este escritor, uma condição indestrinçável do estado de infantilidade - e, por isso, de inferiorização - a que estava sujeito em casa dos pais (Bataille, 1998, p. 131-150).

Casanova, o "libertino clássico" do século XVIII, põe também em relação a experiência vivida e a prática da escrita. Mas é sobretudo a reflexão sobre uma ars vivendi assente no logro e na capacidade de enganar (a perícia de ludibriar os insolentes que "insultam a inteligência" - e que se imaginam capazes de iludir o homem realmente astuto - vivida como dever e prazer) que importará salientar no que concerne ao tema da exteriorização em Casanova. Tal especialidade deve encaminhar o libertino a um movimento perpétuo: aquele que a exerce não pode senão aperfeiçoá-la até ao limite, sob pena de cristalizar numa posição segura, couraçada, estática: a certeza de si mesmo do imprudente e do néscio. Ser mestre nesta arte consiste num tirocínio que conduz ao "esprit", num campo de batalha onde a vitória determina um rumo para aquele que vence e um lugar para aquele que sai derrotado (Vallera, 2019, 279-280).

Quanto ao "divino" marquês de Sade, outra figura que merecerá amplo destaque, dir-seia que a fuga e o deslocamento, assim como a relação entre pensamento e modo de existência, transitam quase por inteiro da vida vivida para uma potência vital da escrita. É o próprio ato de escrever que, aqui, se encontra imbuído de um vigor desenfreado e se expressa na forma de um movimento incessante. A obra de Sade, que viveu cerca de três décadas enclausurado, será examinada na perspectiva de uma pesquisa sempre em curso, um exercício obstinado da razão (textos escritos e reescritos, rasurados e retomados vezes sem conta), nunca resolvido ou acabado, em busca de uma teoria do egoísmo integral e do mal absoluto sintetizada, justamente, na personagem do libertino. Na longa investigação que, de um texto para o outro, vai consagrando a essa personagem ficcional, assiste-se, de facto, a uma sucessão de transformações conceptuais que acompanham a sua própria vida no contexto dos incidentes político-sociais ocorridos em França no final do século XVIII (Blanchot, 1963, p. 15-49). 


\section{A infância como indeterminado}

\subsection{Apresentação do problema e método}

Esta secção expressa um trabalho em andamento, ainda distante de um resultado ou conclusão definitiva, sobre a educação e o por vir da criança a partir de uma problematização genealógica do conceito de infância. A pergunta é, então, que contributos poderíamos elencar para pensar a educação e a criança se encontrássemos nas várias tentativas de determinar, delimitar e definir a infância a potência do indeterminado? Com esta pergunta consignamos um triplo objetivo: i) pensar a infância como indeterminado por força das várias tentativas de a vincular no espaço entre o que já se conhece e o que não se conhece; ii) deslocar a centralidade do por vir da criança na educação para problematizar o futuro como algo impossível de antecipar; iii) reimaginar a educação como algo de intimamente ligado à contemporaneidade, ao estar-a-ser-criança.

Acompanhando o movimento metodológico que se procura expor neste texto, o que aqui se expressa é uma tentativa de variação tópica, fazendo circular nas diversas configurações históricas que a infância assumiu - "aquele cuja fala não é reconhecida", "adulto em miniatura", "criança-brinquedo", "criança salvífica" - o que não se consegue determinar e, como tal, permanece indeterminado. Trata-se de um gesto que, entre os espaços das várias "definições" de infância, pretende traçar uma linha de fuga que ajude a problematizar a infância como indeterminado, fazendo ressoar a ideia de por vir na educação, aqui entendida como futuro, pela multiplicidade das ontologias infantis. A hipótese é que, através da tecedura da narrativa, se possa abrir um mundo de virtualidades que resgate a infância ao seu por vir conforme, oferecendo, na potência do indeterminado, possibilidades de pensar a educação enquanto puro devir.

Uma ideia que talvez acompanhe a delimitação das existências infantis é que ninguém nasce criança, torna-se. Este movimento de algo que se torna sugere que o paradigma criança em si se constrói num aglomerado. O mesmo será dizer que são os agenciamentos históricos, aqui tomados da dupla Deleuze e Guattari (2007), que nos possibilitam revisitar as perguntas "quem é criança?" e "qual criança?" no sentido de colocar em andamento uma genealogia das forças que tendem a capturar e determinar o que pode ou não pode uma criança ser. De certa forma, esses agenciamentos permitem que nos debrucemos sobre uma outra questão, refeita e reformulada de muitas formas ao longo da história desde Platão: o que fazer para canalizar as melhores naturezas para o melhor projeto político? Precisamente, esta demanda impele-nos a pensar que o poder de delimitar modos de existência infantis - quem e qual reside, em larga medida, nas práticas discursivas sobre o lugar ocupado pelas crianças no desenho da polis do futuro. Destacam-se dois conceitos: i) criança e futuro como par inseparável no jogo de forças que incessantemente procuram determinar e delimitar modos de ser criança.

Deste ponto de vista, a infância como indeterminado não corresponderia a um estatuto, ou uma essência do que é ou deve ser uma criança, mas antes a uma possibilidade ou modo de ser que vai para além do que nos é trazido pelos pensadores e pedagogos desde o século 
XVII - um projeto político. Imaginar esta infância não equivale a descrever o que a criança já foi, nem delimitar o que seria no presente. Muito menos esboçar um paradigma criança que seja válido e universal em todos os tempos e contextos. Pelo contrário, procura desde a herança desses legados históricos, que nunca deixaram se de reatualizar, problematizar duas questões essenciais: a da educação, agregada à delimitação de modos de ser capturados pelo desejo de futuro, e a da criança, associada ao desenho e preparação desse futuro. Pretendese, dessa forma, fazer com que essa ideia de infância como indeterminado responda a questões do presente, nas condições em que vivemos, e no interior das práticas e atividades que são as nossas. $\mathrm{O}$ estudo da condição indeterminada da criança corresponderia, assim, a um exercício que nos permite pensar como a educação, através do sujeito-escolar, não cessa de tentar capturar e determinar o que pode ou não pode uma criança ser (Almeida, 2019).

\subsection{Agenciamento criança-arquétipo e o problema do por vir.}

Tomaremos aqui os agenciamentos de forma dupla no modo como circunscrevem historicamente a infância: i) como processo que tende a determinar; ii) como potência para pensar a própria condição de indeterminado. No fundo, o que se pretende expressar é que o gesto que tenta capturar a infância é, também, aquele que nos devolve a sua condição indeterminada. Joga-se, neste último caso, no tabuleiro do devir em lugar de um futuro consubstanciado no desejo de delimitar modos de ser totalmente normalizados e conformes. $\mathrm{O}$ agenciamento enquanto processo que procura determinar o que é uma criança e que, nesse mesmo movimento, devolve a potência indeterminada da infância.

Esta investigação em curso procura, no seu estar a caminho, trazer o gesto de delimitação da infância para (re)pensar o ofício do educador - correspondente, aqui, a qualquer agente que trabalhe no campo geral da educação - como aquele que proporciona e fomenta as condições para uma continuada permanência da criança no seu estar-a-ser (Almeida, 2018b), ao invés daquele que determina em que condições e sob que formas deve uma criança torna-se adulto. Pensar e agir numa ética desterritorializante implica que o próprio investigador seja capaz de se deslocar de si mesmo e dos seus preconceitos, sendo este último o exercício que, através da escrita, se procura aqui ensaiar.

Pensar a infância como indeterminado traz consigo a hipótese de imaginar uma outra ética relacional no campo pedagógico. No encontro entre educador e infância, produz-se o assujeitamento da criança em sujeito escolarizado, tal como conceptualizado, por outra via, na secção anterior. $\mathrm{O}$ argumento que move esta investigação é, então, que a infância como indeterminado se oferece como possibilidade de propor um tempo e um espaço na relação escolar (onde quer que ela se manifeste, seja na escola, na universidade ou no diálogo interior que o investigador mantém consigo mesmo) que cessa de procurar a normalização e a conformidade em direção a um arquétipo omnipresente no ideário político e nos tratados educacionais. Ora, este tempo e espaço consubstanciam-se numa forma de olhar a infância como puro devir, fluido, sempre em fluxo, por oposição à constituição da infância como algo que se determina em relação a um arquétipo. 
Uma investigação que nunca cessa, que está sempre a caminho, permite ao investigador (re)territorializar-se nesse estar-a-fazer. Esta investigação enraíza-se em pesquisas anteriores (Almeida, 2018a) onde se conceptualizou a figura adulta como destino último da criança que passou pelo processo educativo. Isso mesmo é expresso nos tratados educacionais que, até ao século XVII, tratavam a criança como um receptáculo, uma "tábua rasa" a ser escrita e inscrita (Locke, 2019 [1693]). Encontra-se por esta altura a expressão declarada de uma "luta de forças" (Nietzsche, 2005 [1878], p. 7] que separa, definitivamente, a criança dos adultos, isolando-a numa espécie de quarentena antes de ser lançada ao mundo: a escolarização. Aqui, o currículo manifesto e latente representaria o elo a partir do qual o educador prepararia a criança para a vida. Uma vida que lhe é estranha, que está fora de si e necessita ser incorporada. Um currículo constituído em larga medida pelo conhecimento acumulado historicamente e que preparava para a sociedade, fora da sociedade. Nesse sentido, a educação seria o processo que legitima a criança para deixar de o ser e, assim, afirmar-se adulta. A educação seria, assim, um rito de passagem (Boto, 2012) entre-tempos: o da criança e o do adulto.

Desde meados do século XVII que se encontra nos tratados educacionais um arquivo a partir do qual é possível investigar esses agenciamentos que procuram, a cada momento, capturar e determinar o que é e o que deve uma criança ser através de técnicas, saberes especializados e práticas discursivas que encerram a infância em categorias normalizadoras que devem salvaguardar, a um só tempo, o seu por vir e o da sociedade como um todo. É, portanto, a partir dos tratados educacionais que se traça essa relação entre educare e polis, delimitando-se o educador e a criança cada vez mais nova em modos de existência totalmente capturados pela ideia de futuro. É, portanto, neste período que podemos encontrar a emergência e a proveniência (Foucault, 2016 [1971], p. 64-67) de uma transmutação do valor da infância.

O livro A criança e a vida familiar no Antigo Regime de Phillipe Ariès, publicado pela primeira vez em 1988, representa um marco significativo na consolidação da infância como objeto historiográfico; não apenas como parte do elenco de "outras" histórias, mas enquanto "personagem" principal da sua história. Ariès demarca, a partir da forma como as crianças aparecem representadas até meados do século XX, três períodos distintos: i) a criança como adulto em miniatura durante o Antigo Regime; ii) a "criança-brinquedo" e objeto de entretenimento, entre o Renascimento e o Iluminismo; iii) o "novo sentimento de infância" que se instala definitivamente a partir das Luzes. Pode dizer-se que Ariès descreve, num certo sentido, uma delimitação de modos de existência que determinam relações entre adultos e crianças. Assinala "modos de ser criança" demonstrativos de como existe sempre um gesto de fora, do outro, que procura estabelecer o valor e a essência da infância. O "novo sentimento de infância" aparece então como uma (re)configuração da forma como adultos e crianças se relacionam a partir do "valor" atribuído pelos primeiros à "representação" que têm dos últimos.

A palavra infância deriva do latim infantia, que etimologicamente significa "a ausência de fala", "incapaz de falar". O uso da palavra infantes no império romano e posteriormente foi, durante muito tempo, no sentido de determinar aquele que não pode valer-se da sua 
palavra ou cuja palavra não pode ser considerada (Infantia, 2020). Anteriormente, também entre os gregos não havia uma palavra específica para se dirigir às crianças, embora estas apareçam muitas vezes como aquele que não é cidadão, que não pode participar na polis. Veja-se que o cidadão é aquele cuja fala é reconhecida na organização e vida da polis. Para o mundo antigo, a infância determina-se duplamente: i) pelo que ainda não é, pela marca de inferioridade face àquele cuja fala é reconhecida, e ii) pela possibilidade de regenerar a polis, na esperança de um futuro melhor, a partir de uma adequada condução da alma. Qual então o veículo para conduzir a alma, e a que propósito se vincula? A hipótese que aqui se coloca é a de que seria a educação, associada ao objetivo de alimentar e legitimar a fala do futuro arquétipo de cidadão ideal. Podemos, pois, desdobrar o "novo sentimento de infância" trazido por Ariès na seguinte pergunta: qual é o agenciamento do termo criança que encontramos na interseção entre os regimes discursivos pedagógicos e políticos produzidos no âmbito do "novo sentimento de infância"?

Em Rousseau, Pestalozzi e Froebel - três autores paradigmáticos que marcaram a modernidade pedagógica dentro do espírito do "novo sentimento de infância" e que se dirigiram à educação de crianças pequenas -, encontramos a companhia necessária para continuar a nossa problematização. Identifica-se neste trio o princípio fundamental de se dirigir à infância como um período demarcado que representa uma certa pureza da condição humana e que necessita ser cuidado e protegido para seguir a ordem natural do seu desenvolvimento. A natureza da criança é livre, ativa, dócil, pura e facilmente corruptível. A partir destes autores pode-se problematizar o "novo sentimento de infância" como um agenciamento que incorpora três movimentos delimitadores de modos de ser criança totalmente normalizados em direção a um por vir arquétipo.

O primeiro movimento é o que determina a criança a partir de uma certa ideia de essência própria enquanto espelho da natureza humana. A criança tem uma natureza que a diferencia e que necessita ser, por um lado, protegida e, por outro, conduzida sem coação, sem constrangimentos ao seu "desenvolvimento natural" em perfeita harmonia com a natureza.

Essa educação nos vem da natureza, ou dos homens ou das coisas. O desenvolvimento interno de nossas faculdades e de nossos órgãos é a educação da natureza; o uso que nos ensinam a fazer desse desenvolvimento é a educação dos homens; e o ganho de nossa própria experiência sobre os objetos que nos afetam é a educação das coisas (Rousseau, 1979 [1762], p. 12).

[...] Em todas as coisas vive e está uma lei eterna. Esta lei tem sido e está anunciada com clareza e distinção na Natureza (o externo), no espírito (o interno), e na vida que une as duas, para todo aquele cuja mente, através da disposição e da fé, está completamente compenetrada na e impulsionada pela necessidade de que isso não possa ser de outra maneira, assim como para aquele, cuja clara e calma visão mental vê o interior no exterior e através do exterior e vê o procedimento exterior como uma necessidade lógica da essência interior (Froebel, 2001 [1826], p. 1). 
O segundo movimento refere-se ao processo de condução da alma infantil, à questão de como guiar o espírito da criança. Embora livre e ativa, a criança precisa que o seu espírito seja conduzido, sem coação ou prescrição, de forma a não corromper a sua natureza e os seus talentos naturais Froebel (2001 [1826]). A criança deve ser introduzida "em seu mais tenro desenvolvimento no círculo inteiro da natureza que a rodeia" (Pestalozzi, 1894 [1801], p. 67). Cabe ao(à) educador(a) guiar as forças espirituais imanentes na criança respeitando os seus "interesses", as suas "necessidades" e o "seu ritmo natural de desenvolvimento" (p. 72). Pestalozzi e Froebel, tal como Rousseau, escrevem sobre o respeito pela natureza, pelas necessidades e pelo "ritmo natural de desenvolvimento", acrescentando a ideia, tão próxima de nós, de que é necessário um método que promova a "força autónoma" da criança "dentro do contexto da sociedade" ou, nas palavras de Rousseau, de sintonia entre "vontade particular" e "vontade geral". O que se parece afirmar é que o "desenvolvimento natural" implica, de forma definitiva, método e materiais que estejam ao serviço do "conhecimento de si". A criança deve ser conduzida, governada, até ser capaz de se autogovernar, seja de acordo com a "vontade geral", a compressão do "espírito divino" em si e em todas as coisas, ou o domínio da força autónoma "dentro do contexto da sociedade". O caminho é feito através da "psicologização" da "instrução humana", com a grande demanda de que a criança se aperfeiçoe ao ponto de "fazer do que deve o que quer fazer" (Pestalozzi, 1894 [1801], p. 199). Trata-se de aprender o governo de si a partir de métodos e materiais que conduzam a natureza livre e ativa da infância em direção à conformidade.

Deixo-lhe, é verdade, a aparência da independência, mas nunca me foi mais obediente, porque o é por querer sê-lo. Enquanto não pude tornar-me senhor de sua vontade, eu o fui de sua pessoa; não o largava um instante. Agora eu o deixo por vezes só, porque o governo sempre (Rousseau, 1979 [1762], p. 285).

[...] a direção ao caminho dos conceitos claros e distintos se abre mais fácil e seguro do que qualquer outro, e entre tudo o que é claro, nada pode ser mais claro do que a clareza desse princípio, que o conhecimento da verdade procede, no homem, do conhecimento de si mesmo (Pestalozzi, 1894 [1801], p. 86).

A educação, o como conduzir a alma infantil, expressa em diferentes métodos, situa-se entre tempos. Por um lado, deve respeitar a essência livre, ativa e autónoma da criança, por outro, deve conduzi-la em direção ao homem novo. Este homem novo não é mais do que a expressão de um arquétipo que orienta e informa ora a noção particular de essência infantil de cada autor, ora como conduzir a alma infantil em direção a esse devir-adulto-arquétipo. Seja o homem novo de Rousseau, o homem integral de Pestalozzi ou o homem divino de Froebel, todos eles engendram a infância na direção de um futuro conforme. Embora cada arquétipo tenha as suas particularidades, podem destacar-se três ideias transversais a estes autores: i) a criação de uma figura que expressa uma visão de homem; ii) sintonia entre essa visão de homem e o que a polis do futuro necessita para se regenerar; iii) o desenvolvimento da "consciência de si”" e da "futura reflexão de si mesmo" (Froebel, 2001 [1826], p. 51) como 
forma de autogoverno em total conformidade com a "vontade geral" (Rousseau, 1979 [1762], p. 419).

\begin{abstract}
Suscitar as energias do homem - ser progressivamente consciente, pensante e inteligente -, ajudá-lo a manifestar sua lei interior - o divino que há nele - com toda pureza e perfeição, com espontaneidade e consciência - nisso consiste a educação do homem. Ela nos dá, para esses fins, o caminho e os meios. [...] Desenvolver a educação é o caminho que conduz à vida, o único que guia com segurança à realização das aspirações internas da natureza humana e à realização também de suas aspirações externas; o único que mediante uma vida fiel à sua vocação pura, santa, leva à bem-aventurança eterna. Portanto, o divino no homem, sua essência, deve ser, mediante a educação, desenvolvido, exteriorizado e elevado à sua plena consciência. $\mathrm{O}$ homem há-de alcançar a livre-manifestação desse elemento divino que nele atua se expressá-la numa vida consciente e livre. Também a educação, o ensino deve dar ao homem a intuição e o conhecimento do divino, do espiritual e do eterno que existem na natureza exterior, os quais constituem a essência dessa natureza e nela se expressam de um modo permanente (Froebel, 2001 [1826], p. 23-24).
\end{abstract}

O que se procura expressar através destes três movimentos é que a "ideia" de criança e a sua genealogia - emergência e proveniência - surge associada a técnicas de subjetivação (materiais e métodos) que procuram produzir "modos de ser criança" (por exemplo, "criança autónoma", "criança ativa", "criança livre", "criança autogovernada", entre outras) totalmente subordinados a determinados arquétipos: criar o nobre, produzir o bom cristão, engendrar o sujeito útil ao Estado, entre outros. Estes três movimentos sugerem um gesto que captura e determina a alma infantil através da educação da infância, instaurando um regime discursivo que estabelece esta etapa como um rito de iniciação à produção do arquétipo, e que assim define e circunscreve modos de ser (Almeida, 2018b; 2019). O mesmo é dizer que a ideia de criança nunca deixa de operar em relação a um transcendente que lhe é exterior e anterior. O "novo sentimento de infância" outorga modos de existência através de agenciamentos que precedem a criança: é nesse sentido que ninguém nasce criança, mas torna-se.

É através dos discursos dos adultos que antecedem a criança que se engendra e determina a infância e é isso, precisamente, que revela a sua condição de indeterminado. O próprio agenciamento que procura determinar modos de ser criança a partir de uma essência, um método e um arquétipo, é, também, o mesmo que abre uma possibilidade de fuga a modos de existência conformes e que corporiza a indeterminação própria do que está-a-ser. Donde, o desafio seria pensar a criança investida no estar-a-ser da sua contemporaneidade, propondo uma infância que representaria o desvio do sujeito escolar em direção a uma ética e a uma estética da existência que procura articular aquilo que o dispositivo escolar desvincula: arte e vida (Hadot, 1999). 


\subsection{A infância como indeterminado, ou a vida como obra de arte}

$\mathrm{Na}$ secção anterior não se procurou afirmar a positividade de uma certeza, mas apenas uma intenção de tecer linhas de fuga à tradição incorporada (Deleuze \& Guattari, 2007). Esta exteriorização do investigador, não pretende expressar uma conclusão ou solução definitiva, nem sequer desvelar uma verdade até aqui escondida ou por descobrir. O seu desígnio o foi, antes, o de desterritoralizar o sujeito da investigação em relação às suas convicções para, através da escrita, pensar outros modos de existência possíveis. Pesquisa e pesquisador transformam-se, mutuamente, na e pela escrita.

Circulando por um arquivo como aquele que se selecionou, procurando ilustrar-se agenciamentos históricos em tratados pedagógicos de autores relevantes do pensamento educacional europeu, o resultado desta pesquisa nunca poderá ser o de determinar o que é, quem é, e como se é uma criança. É justamente o caráter multiforme das determinações encontradas nestes autores que abre um espaço para o elemento desterritoralizante desta pesquisa: o indeterminado como condição possível da existência.

Quando Rousseau, Pestalozzi e Froebel enunciam uma essência da criança, pura, livre e emulada, esboçam, ao mesmo tempo, uma tentativa de atribuir ao sujeito que nasce por subjetivar uma alma definida a partir do olhar exterior e particular de quem a tenta determinar. Emerge, assim, no interior do primeiro movimento, a tentativa de cada um destes autores em determinar a essência da criança. Ora, é nesta tentativa particular de cada um que se encontra, também, uma polissemia de essências que abre a infância a uma zona de multiplicidade, de indeterminação. Pode-se, assim, estipular o que seria um primeiro contramovimento: o sujeito como multiplicidade.

Com o segundo movimento, ou seja, a enunciação de um método de condução da criança em direção ao seu por vir, Rousseau, Pestalozzi e Froebel determinam o modo de condução e governo da alma infantil. Faz-se necessário especificar como emular as paixões infantis, primeiro através do jogo, para logo depois, mediante um trabalho lúdico, a criança se aperfeiçoar ao ponto de "fazer do que deve o que quer fazer". No confronto do método de condução da alma infantil com os sujeitos a subjetivar, podem despontar formas de produzir indeterminados ou modos de ser impossíveis de antecipar à partida. Surge assim um segundo contramovimento: o método como possibilidade.

Ao anteciparem um arquétipo, os autores definem um por vir que é, simultaneamente, uma forma de delimitar o presente (ocupado pelo trabalho em direção a esse por vir) e um modo de tornar o futuro uma impossibilidade: ninguém devém arquétipo. Encontra-se na ideia de arquétipo uma intenção de refundação do futuro a partir do que cada um dos autores imagina "útil" face às dificuldades e desafios do seu presente. Quando o por vir adulto das crianças se torna o seu presente, o arquétipo em direção ao qual se trabalhou é já passado. $\mathrm{O}$ arquétipo enquanto projeção do futuro expressa a delimitação de modos de existência infantis totalmente determinados por um transcendente. Enquanto impossibilidade, a ideia de arquétipo remete-nos para o caráter indeterminado do futuro, impossível de conhecer, de antecipar, de determinar. Terceiro e último contramovimento: a educação como encontro na contemporaneidade. 
Este trabalho identifica agenciamentos históricos que encerram a criança no interior de modos de existência determinados a priori: são as visões de essência, método e arquétipo que determinam modos de ser criança enquadrados no contexto sócio-histórico de cada autor. O sujeito que nasce por subjetivar - a quem, num primeiro momento, são atribuídas características a priori no sentido de um por vir conforme e adequado às exigências de um homem eternamente renovado (arquétipo) - torna-se criança.

Vimos previamente que os agenciamentos têm uma potência dupla: ora determinar, encerrar ou enclausurar, ora produzir processos de individuação que não partem de nem remetem para essências, mas que permitem uma possibilidade de existência irredutível a qualquer transcendental como arquétipo. É precisamente no confronto de forças entre este agenciamento histórico (que normaliza e universaliza a criança europeia enquanto paradigma) e o sujeito que nasce por subjetivar (multiplicidade pura, indeterminação em devir) que se abrem outras possibilidades de agenciamento. Trata-se de um confronto de forças (que não negam o passado, nem antecipam o futuro) entre aquilo que procura encerrar, capturar e determinar quem e como se torna criança, e o sujeito enquanto multiplicidade (Deleuze \& Guattari, 2007).

É nesta dobra (Deleuze, 2018 [1988]), num dentro e num fora - um passado (memória) e um presente (subjetividade) - que se encontram dois lados de uma única superfície. A relação de um sujeito consigo ou com o seu corpo torna-se um "arquivo" e um "diagrama", uma coleção de subjetivações e um mapa mental traçado com base no passado. Neste caso, o agenciamento assume uma formação histórica, o ser é mapeado ao longo de um eixo de conhecimento. O ser é determinado pelo que é visível e enunciado; pelo exercício do poder, ele mesmo determinado pela relação de forças e singularidades num determinado contexto sócio-histórico. Não se trata, portanto, de dividir a história das instituições ou de subjetivações, mas de estabelecer as suas condições e os seus processos no interior de vincos e dobras que operam nos campos ontológico e social, isto é, que determinam modos de existência. Neste caso, a educação e a escola têm um papel a desempenhar: são máquinas reguladoras da concretização dos agenciamentos históricos. Procuram impedir que as concretizações se desfigurem, ocultem ou ponham em causa a identidade do agenciamento.

Será, pois, na dobra dos agenciamentos que se operacionaliza o seu carácter múltiplo, uma vez que as possibilidades de combinar, conjugar, misturar, mesclar, reunir, agrupar, somar, conectar,, compor e articular os seus elementos remetem para a potência do múltiplo. Agenciar também é produzir multiplicidades, é abrir a existência à inventividade. O que seria, então, um agenciamento que mantém em aberto tantos modos de ser como os que forem concebíveis? Não se trata aqui, como já se afirmou, de ensaiar uma resposta definitiva. Gostaria de sugerir, porém, que mais do que antecipar a utopia de uma sociedade por vir, o que mais importa é, porventura, refletir criticamente sobre uma sociedade que se homogeneizou de tal modo que "nela apenas encontramos a monótona rotação do Mesmo para o Mesmo e o retraimento absoluto de toda a dimensão do Outro" (Prado Coelho, 2012, p. 644). Trata-se de sugerir um estar-a-ser pautado pelo indeterminado.

Para definir este indeterminado da infância, podemos partir de três ideias: i) todas as tentativas de determinação criam novos espaços de indeterminação do sujeito; ii) nunca se 
podem preencher todos espaços indeterminados por mais que se definam métodos de condução da alma infantil; iii) os arquétipos são transcendentes que, apresentando-se como futuros da infância, expressam na verdade o mesmo, aquilo que já se conhece. Dir-se-ia que estamos num espaço de indeterminado, no sentido em que esta multiplicidade constituinte é definida pela sua ausência de orientação, pela sua indeterminação como condição. Temos, então, uma combinação de tendências que incluem abertura, fragmentação, ambiguidade, descontinuidade, heterodoxia, pluralismo, deformação, todas elas conduzindo à indeterminação.

Como seria, então, uma educação que considerasse a infância como indeterminado? Como e sob que condições seria possível uma educação sem essência, método e arquétipo? Não sendo possível uma resposta, pode imaginar-se, todavia, uma educação que se concretiza na sua relação com a vida vivida, aqui e agora, no estar-a-ser que resulta de um constante encontro de forças e afetos. Poder-se-ia pensar a questão da "vida", ou seja, da força que persiste ao longo do tempo e das mudanças que se seguem umas às outras, tal como Deleuze (2000 [1968]) a coloca em Diferença e Repetição. Trata-se de um processo experimental, espontâneo e aberto de transformação alimentado por repetições que produzem diferença, sendo por isso inerentemente inventivas. Trata-se de conceber a vida como um fluxo de tempo indeterminado, sempre diferenciado.

É no conceito de rizoma que a hipótese de imaginar uma infância como indeterminado ganha expressão. Deleuze e Guattari (2007) caracterizaram o rizoma como sendo indeterminado e experimental precisamente porque o afastam de estruturas interpretativas representacionais, como por exemplo os agenciamentos históricos. O rizoma é concebido como uma multiplicidade aberta, e toda a vida é um modo rizomático de mudança sem limites firmes e fixos que procede "do meio para o meio, indo e vindo em vez de começar e terminar" (2007, p. 25). Sob este ponto de vista, a infância deixaria de ser um período de tempo que delimita e determina o termo criança, para passar a ser um modo de existência que convida a experimentar a vida como obra de arte. A luta pela subjetividade é uma batalha para ganhar o direito à diferença, à variação e à metamorfose; é um confronto de forças para conquistar o direito a uma vida em devir.

\section{Conclusão}

Procurámos operar, em diálogo, num plano em que não existe diferença entre o objeto de que se fala e o modo como é fabricado. A demonstração de um modo de fazer enquanto está a ser feito ou, por outros termos, uma conversa sobre o estar-a-ser da pesquisa onde conteúdo e forma constituem um único agenciamento. Existe, portanto, um paralelo entre aquilo que fazemos e a maneira como fazemos. Os objetos a que nos referimos não são préexistentes, foi necessário construí-los e retomar incessantemente a sua construção. Na presença do outro (o coautor, neste caso), a escrita torna-se, com efeito, mais rizomática: o processo dialógico não só desestabiliza e descentraliza, como também amplifica e relança o pensamento para lugares antes imprevistos e surpreendentes. 
Estes dois percursos diferenciados apelam, de modos distintos mas com conceitos comuns, ao que seria uma ética da inventividade. "Sair do lugar que se ocupa" (sem nunca sair por inteiro) no libertino e "estar-a-ser-junto no presente" (sem que seja possível imaginar uma infância que não esteja, aqui e agora, a ser determinada) na criança seriam duas possibilidades de pensar o trabalho de investigação e de tentar enfrentar com menos receio os fantasmas da auto-depreciação e os mecanismos de rarefação da escrita, por um lado, e o intimidante espaço do desconhecido e do infinito da discurso, por outro. Invocamos as evasões do libertino e os jogos da criança como forma de permanecer menos tempo no padecimento da escrevência escolar e de aceder ao multiforme do pensamento e da existência. Trata-se, no fim de contas, de combater dois grandes medos ou bloqueios inerentes à nossa condição de sujeitos escolarizados: o da desconformidade, no âmbito da cognição escolar, e o do descaminho, no confronto com o desconhecido.

A pesquisa, no eterno vai e vem entre escrita, leitura e pensamento, oferece-se também como uma possibilidade de desterritorialização e de transformação da vida. Há, por conseguinte, uma dimensão ética da pesquisa que não se confunde com os jogos identitários da autoria ou da conformidade-desconformidade escolar. A escrita representaria aqui a possibilidade de o investigador se manter em permanente devir. Com esta colaboração, tornou-se possível identificar esses agenciamentos da captura e da saída, do determinado e do indeterminado, do futuro (ou por vir) e do devir, tanto nestas páginas - onde foram instrumentos de diálogo - como, retroativamente, no ato de investigar em si mesmo e nos objetos conceptualizados por cada um. Tais categorias percorrem, em simultâneo, os planos i) da interlocução teórica com outro escritor, ii) da autoconsciência metodológica e da elucidação dos impensados no interior dos quais nos constituímos como sujeitos, e iii) da natureza dos próprios conteúdos da pesquisa. Da comunicação entre estes últimos - o investigador libertino e a criança como indeterminado - resultou a convergência nessa figura em que nos revemos, e que permanece ainda sobremaneira emudecida na área das Humanidades, que é o sujeito escolarizado no momento em que se sente acometido pelo desejo de criar, ou seja, pela necessidade de urdir uma linha de fuga face ao seu "arquivo" ou agenciamento histórico. Escrever e investigar são modos de existência possíveis para esse movimento de exteriorização. Confluem neste sujeito, portanto, a condição de aluno, plenamente interiorizada e submetida a um devir maioritário (aquilo que "implica uma constante" e um "metro padrão" em relação ao qual tudo é avaliado como conformidade ou desvio), e essas forças da exteriorização e do estar-a-ser-junto na escrita, para cujo domínio o escolar foi pouco habilitado, e que correspondem a um devir minoritário (processo singular de desterritorialização alicerçado numa arte dos encontros e na potência de ser afetado) ou a uma trajetória de diferenciação.

O libertino e a criança cumprem aqui, por fim, a função de espelhar o lugar vulnerável e potente do investigador, personagem que oscila entre um dispositivo que o captura e determina e um espaço indeterminado onde se joga a possibilidade de articular o que a escola ostensivamente separa: o estar-a-ser e o estar-a-fazer, a vida e o pensamento. O investigador como modo de ser libertino e a infância na sua condição indeterminada entram em diálogo com as instituições de ensino e pesquisa científica do presente inscrevendo-se na 
multissecular tradição, encabeçada desde o século XVIII pela Universidade alemã, que identifica na investigação, no "direito de tudo dizer" e questionar no espaço público, o cerne da "profissão de fé" académica. Sendo ela o santuário da parrésia questionadora, do livre exercício da razão e da crítica, é, todavia, nas Humanidades (a faculdade menor ou de filosofia, em Kant) que essa dissidência e irredentismo, "na origem e por excelência", se apresentam e manifestam. Como o libertino e a criança - e constituindo estas faculdades quiçá o último refúgio, dentro da Universidade, de pesquisas que se reivindicam do nomadismo e da brincadeira exigentes -, as novas Humanidades, das quais se poderia reclamar um filósofo do futuro, combinam investigação ininterrupta e fragilidade efetiva, desdobramento incondicional da pergunta e vulnerabilidade aos poderes de captura, rarefação e apropriação. É precisamente no vaivém entre perguntar e reconhecer as próprias vulnerabilidades que se abre espaço para o potencial inventivo, para uma permanente transformação de si, seja no contexto escolar ou universitário.

O investigador imerso no seu processo de escrita está alinhado com este estatuto de jure (e não sempre de facto) da academia: por ser "estranho ao poder", não dispõe de poder próprio, assemelhando-se a "uma cidadela exposta, entregue à sorte, pronta a ser tomada", habitualmente "votada a capitular sem condições" (Derrida, 2003, p. 9-17). Exerce, em suma, uma soberania sem poder, que não se posiciona contra nem ao serviço de instituições ou ideologias vigentes, e cujo olhar crítico se dirige, em primeira instância, ao lugar que ocupa e ao que os seus textos lhe solicitam para poderem continuar a florescer.

\section{Notas:}

1. Referimo-nos aqui, simultaneamente, à ideia de que o "pensamento [...] exige que o pensador seja um amigo, para que [...] seja partilhado em si mesmo e possa exercer-se", desenvolvida por Deleuze e Guattari em O que é a filosofia? (1992, p. 85), e à atopia de uma "Sociedade dos Amigos do Texto" fantasiada por Roland Barthes em O prazer do texto (1974, p. 50).

2. Investigações provisoriamente intituladas $\mathrm{O}$ investigador libertino - A pesquisa como exercício de exteriorização do pensamento e de transformação da vida e Educação da infância como rito de iniciação Essência, método e arquétipo.

3. Termo utilizado na acepção de cultura ou gramática escolar moderna. Ver, por exemplo, "Changes in mass schooling: «School form» and «grammar of schooling» as reagents” (2013), de Rita Hofstetter e Bernard Schneuwly.

4. Um célebre parágrafo de Rousseau, citado aliás pelo teórico da polícia Josef von Sonnenfels na sua obra Grundsätze der Polizeiwissenschaft (1787 [1765]) ilustra abundantemente esta ideia:

"É uma grande coisa preservar a paz e a ordem em todas as partes da república; é uma grande coisa manter a tranquilidade no Estado, e o respeito pelas leis. Mas se só isso for feito, ganhar-se-á mais na aparência do que na realidade, porque o governo que se limite à obediência terá dificuldade em fazer-se obedecer. Se é bom que se saiba tratar os homens como eles são, muito melhor é fazer com que sejam o que é preciso ser. A autoridade mais absoluta é a que penetra no que o homem tem de mais íntimo, preocupando-se com a sua vontade não menos do que com as suas ações." [tradução minha] 
5. No sentido de "instigar" ou "dar impulso", pela raiz que auctoritas, em latim, compartilha com o verbo augere ("aumentar" ou "incrementar").

6. São na verdade quatro, mas para este texto referem-se apenas três. O movimento em falta seria o que "determina" a "criança moderna" através da preponderância atribuída à família na condução da sua alma, do seu espírito. A família como primeiro pilar e como elemento nuclear no processo de "desenvolvimento natural". A este propósito, tanto Rousseau, como Pestalozzi e Froebel colocam a centralidade do lugar da criança na vida familiar como algo que deve inspirar o gesto educativo através do cuidar, do afeto e da proteção. Pestalozzi e Froebel atribuem um papel determinante à mãe como figura primeira da educação da "liberdade autónoma", mantendo uma linha de contato com a proposta do autor de Emílio. Neste movimento, pode-se vislumbrar a emergência da incorporação dos hábitos familiares na educação da infância - cuidar, nutrir - e, especificamente, a centralidade da mulher como pastora das almas infantis.

7. Segundo Rafael Godinho, no prefácio a Kafka: Para uma literatura menor (2003, p. 15), "a maioria é sempre assimilada à categoria da «representação», ou seja, está integrada numa generalidade normalizadora e identificatória. Os seus elementos estão incluídos num conjunto global e abstrato que os divide em oposições binárias, determinando uma exclusão entre o que é ou não conforme ao maioritário enquanto norma".

8. "O filósofo do futuro é ao mesmo tempo o explorador dos velhos mundos, cumes e cavernas, e só cria à força de se lembrar de qualquer coisa que foi essencialmente esquecida. Esta qualquer coisa, segundo Nietzsche, é a unidade do pensamento e da vida. Unidade complexa: um passo para a vida, um passo para o pensamento. Os modos de vida inspiram maneiras de pensar, os modos de pensar criam maneiras de viver. A vida ativa o pensamento e o pensamento, por seu lado, afirma a vida." (Deleuze, 2007, p. 18)

\section{Referências}

ALMEIDA, T. O governo da infância: o brincar como técnica de si. Arquivos Brasileiros de Psicologia, 70, spe, p. 152-166, 2018a.

ALMEIDA, T. Currículos e agenciamentos do devir: trânsitos ao redor de Deleuze na delimitação da infância a partir de Emílio de Rousseau. FRACTAL Revista de Psicologia, 30, 3, p. 302-309. doi: https://doi.org/10.22409/1984-0292/v30i3/9582, 2018 b.

ALMEIDA, T. Psicologia do desenvolvimento e a delimitação de modos de ser criança. Devir-adulto, devirsujeito e a educação de infância. In. F. Lemos \& M. L. Nascimento (org.) Biopolítica e Tanatopolítica: A Agonística dos Processos de Subjetivação Contemporâneos (p. 229-249). Editora CRV, 2019.

ÁlVAREZ-URÍA, F. \& VARELA, J. Arqueología de la escuela. Madrid: Ediciones de la Piqueta, 1991.

ARIÈS, P. A criança e a vida familiar no Antigo Regime. Lisboa: Relógio de Água, 1988.

BARTHES, R. Escrever... Para quê? Para quem?. Lisboa: Edições 70, 1975.

BARTHES, R. O prazer do texto. Lisboa: Edições 70, 1974.

BATAILLE, G. A literatura e o mal. Lisboa: Vega, 1998.

BLANCHOT, M. Lautréamont et Sade. Paris: Éditions de Minuit, 1963.

BLANCHOT, M. O espaço literário. Rio de Janeiro: Rocco, 1987.

BLUTEAU, R. Vocabulario portuguez \& latino: aulico, anatomico, architectonico ... Coimbra: Collegio das Artes da Companhia de Jesu, 1713. v. 4.

BOTO, C. A Escola Primária como Rito de Passagem. Coimbra: Imprensa da Universidade de Coimbra, 
2012.

BOURDIEU, P. Homo Academicus. Lisboa: Edições Pedago, 2016.

DELEUZE, G. Diferença e Repetição. Lisboa: Relógio de Água, 2000 [1968].

DELEUZE, G. Espinosa: Filosofia prática. São Paulo: Escuta, 2002.

DELEUZE, G. O Mistério de Ariana: Cinco textos e uma entrevista de Gilles Deleuze. Lisboa: Vega, 2005.

DELEUZE, G. Nietzsche. Lisboa: Edições 70, 2007.

DELEUZE, G. Nietzsche e a Filosofía. São Paulo: Edicões N-1, 2018 [1962].

DELEUZE, G. A Dobra. Leibniz e o Barroco. Campina: Papirus, 2018 [1988].

DELEUZE, G., \& GUATTARI, F. O que é a Filosofia?. São Paulo: Editora 34, 1992.

DELEUZE, G. \& GUATTARI, F. Kafka: Para uma literatura menor. Lisboa: Assírio \& Alvim, 2003.

DELEUZE, G., \& GUATTARI, F. Mil planaltos: Capitalismo e esquizofrenia 2. Lisboa: Assírio \& Alvim, 2007.

DELEUZE, G. \& PARNET, C. Diálogos. Lisboa: Relógio D’Água, 2004.

DERRIDA, J. A Universidade sem Condição. Coimbra: Angelus Novus, 2003.

DERRIDA, J. Geschlecht II: Heidegger's Hand. In Deconstruction and Philosophy: The texts of Jacques Derrida. Chicago \& London: Chicago University Press, 1987.

FOUCAUlT, M. Microfísica do Poder. São Paulo: Paz \& Guerra, 2016 [1971].

FOUCAULT, M. O belo perigo. Belo Horizonte: Autêntica, 2016.

FOUCAULT, M. Segurança, território, população. São Paulo: Martins Fontes, 2008.

FROEBEL, J. H. A Educação do Homem. Passo Fundo UPF Editora, 2001[1826].

HADOT, P. O que é a filosofia antiga?. São Paulo: Loyola, 1999.

HEIDEGGER, M. Introdução à filosofia. São Paulo: Martins Fontes, 2008.

HOFSTETTER, R. \& SCHNEUWLY, B. Changes in mass schooling: "School form" and "grammar of schooling" as reagents. European Educational Research Journal, v. 12, n. 2, p.166-175, jun. 2013.

INFANTIA. In: Dictionnaire des Antiquités grecques et romaines. Disponível em: http://dagr.univ-tlse2.fr/\#. Acesso em: 27/07/2020.

JUNTA DE PROVIDÊNCIA LITERÁRIA. Compêndio histórico do estado da Universidade de Coimbra. Lisboa: Régia Oficina Tipográfica, 1771.

LOCKE, J. Alguns Pensamentos sobre a Educação. Lisboa: Edições 70, 2019 [1693]

MACHADO, J. P. Dicionário Etimológico da Língua Portuguesa. 3. ed. Lisboa: Livros Horizonte, 1977. v. 3.

MOURITSEN, H. The freedman in the Roman world. Cambridge: Cambridge University Press, 2011.

NIETZSCHE, F. Escritos sobre educação. Rio de Janeiro: Edições Loyola, 2003 [1872].

NIETZSCHE, F. Humano, demasiado humano. São Paulo: Companhia das Letras, 2005 [1878]

Ó, J. R. do. Fazer a Mão: por uma escrita inventiva na universidade. Lisboa: Edições do Saguão, 2019.

ONFRAY, M. Contre-histoire de la philosophie t.3: Les libertins baroques. Paris: Grasset \& Fasquelle, 2008.

PESTALOZZI, J. H. How Gertrude teaches her children and an account of the Method. London: Butler and Tanner, 1984 [1801].

PESTALOZZI, J. H. Letters on early education (1818). London: Sherwood, Gilbert, And Piper, 1827 [1818].

PRADO COELHO, E. A Mecânica dos Fluidos. A noite do mundo. Lisboa: Imprensa Nacional Casa da Moeda, 2012. 
POPKEWITZ, T. S. How the alchemy makes enquiry, evidence and exclusion. Journal of Teacher Education, v. 53, n. 3, p. 262-267, mai./jun. 2002.

RANCIÈRE, J. O mestre ignorante. Mangualde: Edições Pedago, 2010.

ROUSSEAU, J. J. Emílio, ou Da Educação. São Paulo: DIFEL, 1979 [1762].

SONNENFELS, J. Grundsätze der Polizei, Handlung und Finanzwissenschaft. München: Johann Baptist Strobel, 1787 [1765].

TYACK, D., \& TOBIN, W. The "Grammar" of Schooling: Why Has it Been so Hard to Change?. American Educational Research Journal, v. 31, n. 3, p. 453-479, set. 1994.

VALLERA, T. \& PAZ, A. L., "O sábio-aprendiz e o efémero lugar da escrita". Educação e Pesquisa, 40, n², p. 483-498. doi: https://doi.org/10.1590/S1517-97022014061415, 2014.

VALLERA, T. "Torna-te o que deves ser": Uma história da polícia como genealogia da escola moderna (1760-1834). Tese (Doutoramento em Educação, Especialidade História da Educação) - Instituto de Educação, Universidade de Lisboa, Lisboa, 2019.

\section{Correspondência}

Tomás Vallera: Doutor em História da Educação pelo Instituto de Educação, Universidade de Lisboa. UIDEF, Unidade de Investigação e Desenvolvimento em Educação e Formação, Instituto de Educação, Universidade de Lisboa.

E-mail: tomasvallera@gmail.com

Orcid: https://orcid.org/0000-0002-4636-0015

Tiago Almeida: Pós-doutorando em História e Filosofia da Educação na Faculdade de Educação, Universidade de São Paulo. Docente na Escola Superior de Educação do Instituto Politécnico de Lisboa. Membro integrado do CIE, Centro de Investigação em Educação do ISPA - Instituto Universitário com financiamento plurianual da Fundação para a Ciência e Tecnologia: UIDB/04853/2020.

E-mail: $\underline{\text { tiagoa@eselx.ipl.pt }}$

Orcid: https://orcid.org/0000-0002-3557-0623

Texto publicado em Currículo sem Fronteiras com autorização dos autores. 